\title{
Cost-based industrial enterprise human capital management
}

\author{
Sergei Glukhov ${ }^{1, *}$, Evgeniya Gonchar $^{2}$ \\ ${ }^{1}$ South Ural State University, Logistics, Economics and Management in Transport, Supply and Distribution Department of Higher School \\ of Economics and Management, Chelyabinsk, Russia \\ ${ }^{2}$ South Ural State University, Accounting, Analysis and Auditing Department of Higher School of Economics and Management, \\ Chelyabinsk, Russia
}

\begin{abstract}
The paper focuses on importance of human capital in development of industrial enterprises, issues of their management and methods of achieving balance between interests of owners and employees. Difference between such concepts as human and labor potential as well as human and working capital is clarified. The special attention is paid to the fact that an effective system of motivation and incentivation of labor is to serve as means of rapprochement of human and labor capital. The authors point out the limited scope of the traditional forms of labor motivation and incentivation mechanisms and highlight the complexity of their encouragement for collective work results. The authors suggest using the cost-based approach to workforce management, which is based on assessment of market and intrinsic value of human capital in view of investment and quality characteristics. The proposed approach is attended by methodological support and operational calculations. The study states that the suggested human capital management model can be introduced into practice, as well as substantiates the necessity for boosting the performance of industrial enterprises and their cost by increasing production, stimulating the staff for selfrealization and self-improvement by bringing the owners' corporate interests closer to the interests of the employees.
\end{abstract}

\section{Introduction}

Improving efficiency of human capital management is one of the most common challenges, faced by modern enterprises. Workforce, who fulfils a number of functions and has a closer relation to specific operations, sees weaknesses in a system of enterprise development management much better than top management. An opportunity of getting desired economic benefit by owners of an enterprise depends on work ethics of staff as well as on its readiness to reveal reserves of enterprise economic efficiency increase. Often employees, seeing gaps in activities of close to them sites and knowing, how to resolve them because of specialization in specific operations, do not put rational suggestions forward to company management and unwish to increase amount of their own work. As a result, weak zones remain uneliminated a great while as long as a talented and attentive manager identify them.

This situation is common in many enterprises. It is obvious that the reason for it is weak mechanism of motivation and incentivation of work and inefficient human capital management system as a whole. Economic losses from it are particularly important in the industry, where specific nature of activities is more complex, and management effectiveness depends on attitude of all employees of a large team to work. In order to identify reserves of economic efficiency increasing, it is important to regulate corporate relations for purposes of improvement of efficiency of human capital management through creating command interest in development of an industrial enterprise.

\section{Ease of Use}

An approach of top management to appraisal of enterprise human capital value is equally important in developing workforce corporate management system. In theory and practice there are known three main approaches to appraisal of human capital value.

According to the first approach, which is called by employers "the cost-based approach", value of human capital is measured through amount of labor costs. It is believed that human capital costs so much, how much a company spends for its maintenance. The utopian nature of such an approach is established by the following circumstances. Firstly, companies offer different wage levels for the same job and the same qualification. Therefore, human capital valuation, made by one enterprise, is not accurate. Secondly, even if a company has a quite functioning system of motivation and incentivation of labor, workers do their best as far as it mainly corresponds with financial incentives. In this case we can not speak about an objective evaluation of all workforce opportunities and consequently about human capital value.

Corresponding author: glukhovsv@susu.ru 
In accordance with the second approach, which is called "the investment approach" [8, 5, 3, 14], human capital value is measured through amount of investment in education, training and health of workforce. It is believed that human capital is worth as much, how much it is spent on education, training and health support of staff. This approach is also questionable for the reason that it is impossible to consider return on investments. Investments in one worker can bring benefit to an enterprise, while investments in other will not. This is due to the fact that not all workers can effectively apply their knowledge in practice, bringing benefit to an enterprise. Not all workers think outside the box and can solve non-standard problems in practical activities. For example, there are even situations, when employees, in whom an enterprise invested nothing, solved practical problems better and acted as initiators of projects, while the other workers, whose education and training were invested by enterprise owners, did not bring real benefit to a company. It follows that investment cost does not match with actual value of human capital.

In concordance to the third approach, which is not so popular yet and which we would call "the qualitative approach", human capital value is determined on the basis of its quality. This approach is more reasonable, because it allows taking into account real benefit, which may be brought to a company by every employee of the work collective.

Nevertheless, in the opinion of the authors, individual application of each approach does not allow to appraise human capital value completely and objectively. The combination of the investment approach and the qualitative one is deemed to be the most correct. Concerning the investment approach, we mean value of investments in education, training and health support of workforce without reference to a specific source of investment. It does not matter, who has invested in education and training of an employee: the company, the employee himself or the state. In this case it is important that it is of some value to the employer. The use of the qualitative approach makes allowances in valuation of human capital, as it enables taking into account individual abilities of employees at acquisition and application of knowledge, skills and experience.

Thus, for appraisal of real human capital value it is advisable to use the integrated investment and qualitative approach, which may be the basis for elaboration of effective incentivation mechanisms in system of industrial enterprise development management. However, issues of methodology for assessing human capital quality and methodology for human capital management based on the integrated investmentqualitative approach are not sufficiently elaborated in science yet. Therefore, the aim of this paper is to develop a comprehensive methodology for assessing human capital value on the basis of the integrated investmentqualitative approach and its application under generation of an effective system of management of industrial enterprise human capital based on the cost approach.

3 Thesis Statement

We set the following objectives for this goal achieving within the framework of this paper.
Firstly, it is necessary to clarify differences between such close concepts as human and labor potential, human and working capital in order to specify nature of human capital quality.

Secondly, it is required to elaborate a methodology for assessing human capital value on the basis of the integrated investment-qualitative approach.

Thirdly, there is need to develop a methodological support of human capital management system based on the cost approach.

Fourthly, it is obligatory to carry out operational calculations in assessment of human capital value in its management system in order to confirm practical relevance of the author's model.

\section{Theoretical Part}

Such close categories as capital, human capital, working capital, potential, human potential and labor potential are to be considered in order to clarify the nature of the concept of human capital.

The concept of human capital was formed in the process of overcoming the traditional views on capital, which essence was explained for the first time by K. Marx. "...Capital is definite social relation, which is represented in the thing and gives this thing a specific social tone" [9]. At the beginning of the 20th century I. Fisher suggested considering as capital anything and everything, which matches the criteria of earnings generation for specified time, provided that any income is always a product of one of the capital types [7]. Under this approach capital is understood as any stock of goods, which may accumulate and produce a profit.

T. Schulz [16, 17, 18, 19] and his follower G. Becker, who have formulated the components of human capital (knowledge, production skills and motivation) in 1960 , are justly the founders of the definition of "human capital" [6]. It should be noted that T. Schultz shared the concepts of "human capital" and "human potential", arguing that "all human resources and powers are either inborn or acquired. Everyone is born with a set of individual genes, determining its inborn human potential. Goodness, acquired by a human, which may be stimulated through corresponding investments, is called human capital" [16]. A number of scientists, including L. Thurow [10], Edwin G. Dolan and David E. Lindsey [3], S. Fischer and R. Dornbusch [15], L. I. Abalkin $[11,13]$, A. I. Dobrynin and S. A. Diatlov [1], G. N. Tuguskina [4], interprets the essence of the category of "human capital" as total, universal potential of human labor.

According to V. N. Belkin, human capital includes final performance, effectiveness of labor activity of an employee. In other words, when it comes to human capital, we mean human abilities and qualities, which are really involved in the production process, whereas potential productive capacity of a human is called labor potential $[20,21]$. This point of view is the closest one to our attitude, but some points are to be clarified. Proceeding from the common concept of potential, which derives from the Latin word "potentia" and means 
strength, power, opportunity and ability, which exist in the open form and may manifest under certain conditions [2], we clarify the concepts of "human potential" and "labor potential". Human potential is to be understood as a set of inborn and acquired human capabilities, which exist in the open form and are able to appear under certain circumstances in any living environment. Labor potential is not so wide concept, which, in the opinion of the authors, is to be understood as a set of inborn and acquired human capabilities, which exist in the open form and are able to appear under certain conditions in labor activity (a working life).

According to the authors, human capital of a company is a percent of labor potential, already embodied in a company or possible to be embodied. Then, working capital of a company is an integral part of human capital and represents only that part of labor potential, which is actually embodied in labor force of an enterprise. In other words, human capital differs from labor capital: in the first case this is in reference to all explicit and implicit human capacities to act productively, and in the second case - only to those human capabilities, which straight manifest in work. Obviously, an effective system of motivation and incentivation of labor may act as means of rapprochement of human and labor capital [12].

The exact concept of "quality" should follow us to interpretation of the essence of the category of "human capital". It is commonly known that generally the quality is a combination of essential features, properties, characteristics, which distinguish an object or an occurrence from the other and give definition to it. Thereafter the quality of human capital is a set of essential properties and characteristics of human resources. It makes sense to carry out assessment of human capital quality, using a points system, marking investment and qualitative characteristics of employees. Investment characteristics: 1- Education, 2 - Advanced professional training, 3 - Health. Qualitative characteristics: 4 - Total relevant professional experience, 5 - Length of service with a company, 6 Promptness, 7 - Initiativity, 8 - Decision-making ability, 9 - Operational efficiency, 10 - Self-sufficiency, 11 Competence, 12 - Innovation activity, 13 - Teamwork skills, 14 - Social skills, 15 - Discipline, 16 - Learning capability, 17 - Self-development capability, 18 Economic activity, 19 - Labor capacity.

Based on the presented points system, which criteria list may be extended, it is possible to form a ranking of every employee in a company (quality of individual capital of an employee) by the Formula 1:

$$
Q H C_{n}=\sum_{i=1}^{19} P_{i}^{n}
$$

where $Q H C_{n}$ - quality of individual capital of an nemployee, point;

$P_{i}^{n}-$ a number of points within a parameter $\mathrm{i}$ of $\mathrm{n}$ employee, point;

i - a parameter; $\mathrm{n}$ - an employee.

Then the total amount of human capital quality may be determined using the Formula 2:

$$
Q H C=\sum_{n=1}^{m} Q H C_{n}
$$

where $Q H C$ - quality of human capital of an enterprise, point.

It is possible to estimate value of human capital of an apprised company based on the data of labor market analysis, which allows determining market wage of corresponding levels of employees. At the same time market wage is to be understood as the maximum for every quality level of individual capital in the country, taking into account that human capital is resilient and is differently estimated by the market in every region that determines the market value of human capital. Furthermore, a certain period is to be considered under evaluating the total human capital cost. For example, it may be an average term of company project implementation, as it is reasoned to believe that valuation of human capital is to be carried out, taking into account a forecast period, which is used under evaluation of provided revenue from projects. An average length of service with a company may be used as an evaluation period.

Based on the foregoing, market value of human capital may be determined by the Formula 3:

$$
M V H C=\sum_{n=1}^{m} \frac{Q H C_{n}}{Q H C_{R . W .}^{n}} \cdot M S_{R . W}^{n} \cdot T_{A}^{n}
$$

where $M V H C$ - market value of human capital of a company, rub.;

$Q H C_{R . W .}^{n}$. quality of human capital of the best employee, compared with a n-employee of an enterprise, point;

$M S_{R . W}^{n}$ - the maximum market wage of the best employee, compared with a n-employee of an enterprise, $\mathrm{rub} . / \mathrm{month}$;

$T_{A}^{n}$ - an average term of work (length of service) of a n-employee of an enterprise, months;

$\mathrm{m}-\mathrm{a}$ number of employees in an enterprise.

However we must distinguish market value of human capital and economic benefit of an enterprise from possession of this capital. Economic benefit of an enterprise from possession of human capital is to be understood as economy and income, arising from the use of human labor (Formula 4).

$$
E B_{\text {h.c. }}=M V H C-W F \cdot T_{A}+I R+C S
$$

where $E B_{\text {h.c. }}$ - economic benefit of an enterprise from possession of human capital, rub.

$W F$ - monthly wages fund, rub.; 
$T_{A}$ - an average term of work (length of service) of employees in an enterprise, months;

$I R$ - increase in revenues of an enterprise for the period, rub.;

$C S$ - cost savings of an enterprise, rub.

The reasoning of evaluation of economic benefit of an enterprise from ownership of human capital predefines possibility to consider it as intrinsic value of human capital.

Comparing intrinsic value of human capital (economic benefit of an enterprise from possession of human capital) and market value (identifying difference between them), we get an amount, which may be considered as increase in cost of human capital (Formula 5).

$$
A V_{\text {h.c. }}=E B_{\text {h.c. }}-M V H C=I R+C S-W F \cdot T_{A}
$$

where $A V_{\text {h.c. }}$ - increase in cost of human capital of a company, rub.

Regarding applying the Formula 5 we make the following reservation: values of revenue increment and cost savings are to be analyzed over the same period under allowance of average term of work (length of service) of workforce in a company.

It is possible to form a separate balance sheet statement (let us call it balance sheet statement of human capital), using the figures of the given methodology for assessing value of human capital. The assets show intrinsic value of human capital, the liabilities - its market value and growth.

The proposed system of valuation of human capital may be taken as a basis of motivation and incentivation of labor. In actual practice it is not always possible to draw a parallel between eventual outcomes and individual contribution of employees. Any particular achievement is a result of teamwork, where performed by employees functions are integrated. The cost-based approach in management of human capital can be used in order to distribute overall obtained economic benefit. In this case the mechanism of motivation and incentivation of labor has a bilevel structure.

The traditional forms of motivation and incentivation of labor are realized at the first level through encouragement of individual achievements that is possible, when association between labor input of an employee and obtained enterprise economic or other kind of benefit may be obviously observed. The costbased approach is offered to be applied at the second level of mechanisms of motivation and incentivation, especially where there is a question of distribution of economic performances, achieved by a team.

We enlarge upon the point of the second level of the mechanism of motivation and incentivation of labor. It is important to bear in mind that under its implementation the final economic results of a company are achieved not only through the use of human capital. At this point there are important financial, organization, innovation and market capital and commercial goodwill, contributing to efficiency of an enterprise and promoting formation of its intrinsic value in addition to human capital.

Financial capital makes contribution by funding current and strategic business needs. Organization capital contributes in the form of corporate standards and rules of behaviour, work of units and staff, organization of business processes, ensuring effective communication within workplace for the benefit of achieving current and strategic objectives and solving operational tasks of an enterprise. Innovation capital, consisted of costs of developed and implemented innovation projects, contributes to strategic development of an industrial enterprise. Market capital is involved in development of an enterprise through established business contacts with buyers, customers, suppliers and contractors.

Commercial goodwill provides additional benefit of a company with a high credit rating, fiscal discipline and trust of partners through simplification of procedures for acquisition of credit resources, empowerment to use investment tax credit and lack of likelihood of capital pulling out of business by its founders. All these admit that it makes sense to distribute final economic results at first between a company, represented by its owners, and human capital and then to distribute economic benefit, providing human capital increment, between employees. Let us refer to developing methodological support of the second level of implementation of mechanism of motivation and incentivation of labor.

A proportion of economic benefit of a company, accounted for human capital, may be determined by means of the Formula 6.

$$
S_{\text {h.c. }}=\frac{I V_{\text {h.c. }}}{I V_{\text {h.c. }}+I V_{\text {o.c. }}+I V_{\text {i.c. }}+I V_{\text {f.c. }}+I V_{\text {m.c. }}+I V_{\text {r.c. }}}
$$

where $S_{\text {h.c. }}$ - a share of intrinsic value of human capital in intrinsic value of an enterprise, taken as a basis of total economic needs distribution;

$I V_{\text {h.c. }}$ - intrinsic value of human capital of an enterprise, rub.;

$I V_{\text {o.c. }}$ - intrinsic value of organization capital of an enterprise, rub.;

$I V_{i . . c .}$ - intrinsic value of innovation capital of an enterprise, rub.;

$I V_{f . c .}-$ intrinsic value of financial capital of an enterprise, rub.;

$I V_{\text {m.c. }}$ - intrinsic value of market capital of an enterprise, rub.;

$I V_{\text {r.c. }}$ - intrinsic value of commercial goodwill of an enterprise, rub.

Value of enterprise economic benefit, accounted for human capital (we call it a collective bonus pool), may be determined according to the Formula 7.

$$
B F_{c .}=A V_{\text {h.c. }} \cdot S_{\text {h.c. }}
$$


where $B F_{C}$. - collective bonus pool, rub.

A distributed amount of economic benefit of an enterprise, accounted for a particular employee, may be calculated by virtue of the Formula 8 .

$$
B F_{W}^{n}=B F_{c} \cdot \frac{Q H C_{n}}{Q H C}
$$

where $B F_{W}^{n}$ - a distributed amount of economic benefit of an enterprise, accounted for a n-employee, rub.

Summarizing the undertaken study, we draw attention to those results, which contain scientific novelty.

1. Difference between the concepts of "human potential", "labor potential", "human capital" and "labor capital" is clarified. Human potential is a set of inborn and acquired skills and human capabilities, which exist in the open form or can appear under certain conditions in all living spheres.

Labor potential is a set of inborn and acquired skills and human capabilities, which exist in the open form or can appear under certain conditions in the course of labor activity (work life).

Human capital is a share of labor potential, which is already embodied in a company or is possible to be embodied therein.

Labor capital of an enterprise is an integral part of human capital and represents only that portion of labor potential, which is actually embodied in labor activity of an enterprise.

2. The methodology of human capital appraisal on the basis of the integrated investment and qualitative approach is elaborated. Quality of human capital, which is estimated on investment and quality characteristics, and the corresponding market and internal appraisal of value are the foundation of the methodology.

3. The methodological support of human capital management system is developed based on the cost approach. The instrumentarium of labor motivation and incentivation system is its foundation. The methodology of distribution of collectively obtained economic benefit of an enterprise between its owners and its human capital with the further distribution between its employees is included therein.

\section{Practical Relevance}

In order to justify the practical relevance of the proposed methodological support of human capital management system we carry out operational calculations, using project targets of a small industrial enterprise.

At first, we assess quality of human capital of an enterprise and compare individual performance with performance of the best employees (Table 1).
Table 1. Appraisal of Human Capital Quality of an Enterprise.

\begin{tabular}{|c|c|c|c|c|c|}
\hline \multirow[b]{2}{*}{ Employee } & \multicolumn{3}{|c|}{ Quality of human capital } & \multirow[b]{2}{*}{$\begin{array}{c}\text { Average } \\
\text { length of } \\
\text { work, } \\
\text { months }\end{array}$} & \multirow[b]{2}{*}{$\begin{array}{c}\text { Maximal } \\
\text { market } \\
\text { wage, } \\
\text { rub. }\end{array}$} \\
\hline & \begin{tabular}{|c|} 
Quality of \\
human \\
capital of \\
an \\
company, \\
point
\end{tabular} & $\begin{array}{c}\text { Quality of } \\
\text { the best } \\
\text { human } \\
\text { capital, } \\
\text { point }\end{array}$ & $\begin{array}{c}\text { Correlation } \\
\text { (2):(3) }\end{array}$ & & \\
\hline Employee 1 & 89 & 145 & 0,613793 & 48 & 100000 \\
\hline Employee 2 & 116 & 156 & 0,743590 & 30 & 135000 \\
\hline Employee 3 & 94 & 122 & 0,770492 & 60 & 80000 \\
\hline Employee 4 & 138 & 150 & 0,920000 & 84 & 130000 \\
\hline Employee 5 & 141 & 169 & 0,834320 & 54 & 150000 \\
\hline Total & 578 & 742 & - & 55,2 & - \\
\hline
\end{tabular}

The market value of human capital, calculated according to the Table 3, is 26460494 rub.

Assuming that increase in revenues and skimping on enterprise cost in the whole for a period, equal to the average length of work in a company, is 27600000 rub., the payroll for the same period - 12420000 rub., then intrinsic value of the human capital is 41640494 rub., and its share in the intrinsic value of the company will be $16 \%$, when the intrinsic value of the organization capital is 5000000 rub., the intrinsic value of the innovation capital - 80000000 rub., the intrinsic value of the financial capital - 90000000 rub., the intrinsic value of the market capital - 20000000 rub., the intrinsic value of the commercial goodwill - 20000000 rub., and the general intrinsic value of the company, taking into account the intrinsic value of the human capital, is 256 640494 rub.

Then, the overall economic benefit of the enterprise for the average length of work in the company accounts for 15180000 rub., where the share of the human capital accounts for 2462989 rub., which is 44619 rub. per month.

Table 2. Distribution of the Collective Monthly Bonus Pool.

\begin{tabular}{|c|c|c|}
\hline Employee & $\begin{array}{c}\text { Correlation of } \\
\text { individual and } \\
\text { the best quality } \\
\text { of human capital } \\
\text { (Table 1) }\end{array}$ & $\begin{array}{c}\text { Distributed economic } \\
\text { benefit of the } \\
\text { enterprise per } \\
\text { employee, rub. }\end{array}$ \\
\hline Employee 1 & 0.613793 & 6870 \\
\hline Employee 2 & 0.743590 & 8955 \\
\hline Employee 3 & 0.770492 & 7256 \\
\hline Employee 4 & 0.920000 & 10653 \\
\hline Employee 5 & 0.834320 & 10885 \\
\hline Total & - & 44619 \\
\hline
\end{tabular}

In conclusion to the practical section, we distribute the collective monthly bonus pool among the employees in proportion to the ratio of their individual qualities and the best quality of human capital of the relevant category (Table 2).

The obtained results indicate that different levels of the individual qualities of employees correspond to 
different amounts of the distributed collective bonus. The higher quality of individual employee is, the more amount of distributed collective bonus is. Such a system of collective incentivation for team results, combined with the traditional encouragement for individual performance, allow improving efficiency of the mechanism of motivation and, thus, improving effectiveness of human capital management for the benefit of industrial enterprise development.

\section{Conclusions}

The results of this study confirm that it makes sense to implement human capital management system, based on the cost approach, in practice of industrial enterprises. Human capital as well as financial, organization, innovation, market capital and commercial goodwill contribute to economic benefit gaining and increment of its internal and market value. Therefore, determination of correlation of material incentivation for employees with contribution to intrinsic value of enterprise human capital promotes balance of interests of employees and owners and creates conditions for effective labor motivation. The possibility to provide command interest in improving economic efficiency of an enterprise and its cost, using implementation of the author's model, is stipulated by the following circumstances.

Firstly, distribution of economic benefit between an enterprise, represented by the owners, and its workforce, represented by the human capital, in proportion to a share of cost components in intrinsic value of a company determines strengthening corporate relationships and interest of all employees in company development.

Secondly, application of evaluation of human capital quality as a part of value appraisal system in distribution of economic benefit creates conditions for incentivation of employees to self-improvement, development and self-realization that will improve efficiency of an enterprise in the future.

Embodiment of the results of the above circumstances predetermines a cycle of positive effects in industrial enterprise development system through improving productivity and motivation to self-realization in work and development of workforce.

The work was supported by Act 211 Government of the Russian Federation, contract № 02.A03.21.0011.

\section{References}

1. A.I. Dobrynin, S.A. Diatlov, V.A. Konnov, S.A. Kurganskii, Productive Power of The Human: Structure and Forms of Appearance (SaintPetersburg University of Economics and Finances, 1993)
2. A.V. Babkin, A.A. Moshkov, News of the St. Petersburg State Economic University, 6(84), 46-47 (2013)

3. E.G. Dolan, D.E. Lindsey, Market. Microeconomic Model (Copyright, 1992)

4. G. Tuguskina, Personnel Management, 3, 205 (2009)

5. G.A. Khmeleva Human Capital as A Condition of Formation of Innovation Economy of The Region: monograph (SaSMU, 2012)

6. G.S. Becker, Economic Analysis and Human Behaviour (Selected Works on Economic Theory, 2003)

7. I. Fisher, 15-17 (1927)

8. I.V. Soboleva, Pardoxes of Human Capital Measuring: Scientific Report (Institute of Economics of RAS, 2009)

9. K. Marx and F. Engels, Capital (1961)

10. L. Thurow, Investment in Human Capital (Academia, 1970)

11. L.I. Abalkin, Russian Strategic Response to The Challenges of The New Century (Ekzamen, Moscow, 2004).

12. M.K. Akhtiamov, E.A. Gonchar, Economics and Entrepreneurship, 8-1(61-1), 522-527 (2015)

13. R.D. Galieva, V.A. Mishin, Collection of Conferences of Research and Development Centre "Soziosfera", 11, 71-72 (2012)

14. R.M. Nureev, Russia: Characteristics of Capacity Buildings (Norma, 2009)

15. S. Fisher, R. Dornbusch, R. Schmalensee, Economics (Delo, 1994)

16. T.W. Shultz, Human Capital in the International Encyclopedia of the Social Sciences (1968)

17. T.W. Schultz, University of California Press, 149166 (1981)

18. T.W. Schultz, Investment in Human Capital: the Role of Education and of Research (Free Press, 1971)

19. V.N. Belkin, V.I. Vinogradova, Innovation Activity of Human Capital (Institute of Economics of UD of RAS, 2009)

20. T.W. Schultz, The Economic Value of Education (Columbia University Press, 1963)

21. T.W. Schultz, Investment in Human Capital (Economic Growth - an American Problem, Englewood Cliffs, 1964) 